\title{
Exploring the future of the institutional landscape of the oceans beyond national jurisdiction
}

\author{
Alex G. Oude Elferink
}

Correspondence

Email: a.oudeelferink@uu.nl
A comprehensive regime for biodiversity in marine areas beyond national jurisdiction ( $A B N J)$ is currently being negotiated at an intergovernmental conference convened by the United Nations. One of the aspects of the negotiations concerns the institutional arrangements of the treaty that is to be developed. Many activities in ABNJ currently are being regulated at the sectoral and/or regional level, raising the question how the institutional arrangements of the treaty are to interact with these existing frameworks. The article first provides some further information on the background to the current negotiations, then looks at the current status of those negotiations and next attempts to sort out and appraise the options for institutional arrangements. Three main approaches have been tabled: a global approach, a regional approach or a combination of the two. The article concludes that the institutional arrangements of the treaty may be the most critical element in accomplishing an effective regime for the sustainability of ABNJ.

\section{1 | INTRODUCTION}

Without doubt, one of the main frontiers in developing the environmental governance of the oceans currently is constituted by the negotiations at the United Nations (UN) on biological diversity beyond national jurisdiction. Ocean space beyond national jurisdiction is comprised of the high seas and the international seabed area (the Area), jointly referred to as areas beyond national jurisdiction (ABNJ). ${ }^{1}$ These areas make up more than 50 percent of the oceans. Although certain aspects of the governance and legal regime of $A B N J$ have been elaborated in considerable detail, ${ }^{2}$ it is generally considered that

\footnotetext{
${ }^{1}$ These areas and their legal regime are defined in the United Nations Convention on the Law of the Sea (adopted 10 December 1982, entered into force 16 November 1994) 1833 UNTS 3 (LOSC) art 1(1)(1) and Parts VII and XI. Part XI of the Convention has been adapted by the Agreement relating to the Implementation of Part XI of the United Nations Convention on the Law of the Sea of 10 December 1982 (adopted 28 July 1994, entered into force 28 July 1996) 1836 UNTS 42 (Part XI Agreement).

${ }^{2}$ This in particular concerns the regime for mining set out in Part XI of the LOSC and the Part XI Agreement, which have been further elaborated by the International Seabed Authority's (ISA) Mining Code (on the latter, see further The Mining Code <https://www.isa.org.jm/ mining-code>). The regime for certain fisheries on the high seas as contained in the LOSC has been elaborated significantly through the Agreement for the Implementation of the Provisions of the United Nations Convention on the Law of the Sea of 10 December 1982 Relating to the Conservation and Management of Straddling Fish Stocks and Highly Migratory Fish Stocks (adopted 4 August 1995, entered into force 11 December 2011) 2167 UNTS 3 (Fish Stocks Agreement). Various institutions at the global and regional level, such as the International Maritime Organization, the ISA and regional fisheries management
} organizations and arrangements have addressed the regulation of specific activities in ABNJ. this regime contains significant gaps and in particular does not offer a sufficient level of protection for the marine environment of $A B N J$. The awareness of these gaps has grown together with the increase of activities in ABNJ since the adoption of the UN Convention on the Law of the Sea (LOSC) in 1982. These gaps include: the lack of regional environmental instruments covering $A B N J$ (most of these regimes only apply to areas within national jurisdiction); the lack of coordination between existing sectoral and regional institutions; and the lack of sufficiently detailed legal obligations.

The road towards the negotiation of an instrument to set up a comprehensive regime for $\mathrm{ABNJ}$ has been long. ${ }^{3}$ In particular since the latter half of the 2000s, the Convention on Biological Diversity $(C B D)^{4}$ started dealing with the protection and preservation of biodiversity in ABNJ. ${ }^{5}$ The UN General Assembly, which since 1945 has

\footnotetext{
${ }^{3}$ For an overview of this process, see, e.g., D Freestone, 'The UN Process to Develop an International Legally Binding Instrument under the 1982 Law of the Sea Convention: Issues and Challenges' in D Freestone (ed), Conserving Biodiversity in Areas beyond National Jurisdiction (Brill/Nijhoff 2019) 3; G Wright et al, The Long and Winding Road: Negotiating a Treaty for the Conservation and Sustainable Use of Marine Biodiversity in Areas beyond National Jurisdiction (Institut du Développement Durable et des Relations Internationales 2018).

${ }^{4}$ Convention on Biological Diversity (adopted 5 June 1992, entered into force 29 December 1993) 1760 UNTS 79 (CBD).

${ }^{5}$ For a brief overview of the activities under the CBD, see, e.g., P Drankier, 'Marine Protected Areas in Areas beyond National Jurisdiction' (2012) 27 International Journal of Marine and Coastal Law 291, 298.
} 
been the main forum for initiating the further development of the legal regime for the oceans, started addressing this issue in the first half of the 2000s, eventually resulting in the convening of an intergovernmental conference, for which four substantive sessions have been planned currently. ${ }^{6}$ This whole process is also referred to as the BBNJ process, with BBNJ standing for biodiversity beyond national jurisdiction. The conference has been charged with elaborating 'an international legally binding instrument under the LOSC on the conservation and sustainable use of marine biological diversity of $[A B N J]{ }^{7}$ One of the aspects of the instrument, which is also referred to by the acronym ILBI (for international legally binding instrument), the conference is considering is its institutional framework. Many activities in ABNJ currently are being regulated at the sectoral and/ or regional level, raising the question how the institutional arrangements of the ILBI are to interact with these existing frameworks. In that connection, it may be noted that the General Assembly has instructed the conference that the ILBI 'should not undermine existing relevant legal instruments and frameworks and relevant global, regional and sectoral bodies'. ${ }^{8}$ This article discusses various aspects related to the institutional arrangements that may be included in the ILBI. The remainder of this article first provides some further information on the background to the current negotiations at the intergovernmental conference. It then looks at the current status of those negotiations. The next section focuses on sorting out and appraising the options for institutional arrangements. Finally, the main points of the article are summarized in the conclusion.

\section{2 | BACKGROUND TO THE ILBI NEGOTIATIONS}

The current negotiations on the ILBI have their origin in several issues in relation to $A B N J$ that came to the fore after the conclusion of the LOSC in 1982: ${ }^{9}$

- Agreement at the political level that at least 10 percent of the world's oceans should be protected areas; ${ }^{10}$

- The realization that the genetic material of living resources of in particular the seabed beyond national jurisdiction had commercial value and might produce significant economic benefits;

${ }^{6}$ The Conference has been convened on the basis of United Nations General Assembly Resolution 72/249. UNGA 'International Legally Binding Instrument under the United Nations Convention on the Law of the Sea on the Conservation and Sustainable Use of Marine Biological Diversity of Areas beyond National Jurisdiction' UN Doc A/ RES/72/249 (19 January 2018) (UNGA Resolution 72/249).

${ }^{7}$ ibid para 1.

${ }^{8}$ ibid para 7.

${ }^{9}$ For a further discussion of this point, see for instance the literature mentioned in $\mathrm{n} 3$.

${ }^{10} \mathrm{CBD}$ 'Decision X/2, The Strategic Plan for Biodiversity 2011-2020 and the Aichi Biodiversity Targets' UN Doc UNEP/CBD/COP/DEC/X/2 (29 October 2010) Target 11 Several MPAs in ABNJ have been designated through actions at the regional level, including in the North-East Atlantic and the Southern Ocean. For a recent discussion of this regional practice, see AG Oude Elferink, 'Coastal States and MPAs in ABNJ: Ensuring Consistency with the LOSC' (2018) 33 International Journal of Marine and Coastal Law 437, 455-463.
- The view that the environmental impacts of activities in ABNJ should be better monitored through strategic environmental assessments (SEAs) and environmental impact assessments (EIAs); and

- The wish of developing States for effective capacity building and transfer of marine technology mechanisms.

The LOSC itself does not address these matters in detail and/or is lacking in effective means for their implementation. For instance, the Convention is silent on the legal status of the genetic material of living resources in the Area. This has led some to argue that the legal regime of freedom of the high seas is applicable to these resources, while others argue that the regime of common heritage of humankind provides the relevant legal framework. ${ }^{11}$ This difference of views has also permeated the BBNJ process, and has obvious implications for the institutional structure of the ILBI. Applicability of the regime of high seas freedoms, implying freedom of access and the absence of benefit sharing with the international community, would require little if no international institutional mechanism, while regulated access and such benefit sharing obviously would require such mechanism.

It has been argued that Article 194(5) of the LOSC provides a legal basis for the establishment of marine protected areas (MPAs) in ABNJ. ${ }^{12}$ However, apart from that rudimentary provision and inter alia the duty of cooperation enshrined in Article 197 of the LOSC, there is nothing in the form of procedures for the designation and management of such areas under the Convention. Work on this matter has among others been taken up in the framework of the $\mathrm{CBD}^{13}$ and in regional environmental and fisheries regimes. As a consequence, the conference is not only faced with the question how to implement the basic rules of the LOSC, but also how this implementation should relate to existing work on the matter.

Monitoring and environmental assessment is addressed in Articles 204-206 of the LOSC. Again, this concerns obligations of a general nature that, to be effective, would require further operationalization as regards the specific substantive and procedural obligations. ${ }^{14}$ The same can be said to apply to capacity building and the transfer of marine technology. Part XIV of LOSC deals with this matter, but is largely hortatory in nature.

\footnotetext{
${ }^{11}$ See, e.g., E Morgera et al, 'Summary of the First Session of the Intergovernmental Conference on an International Legally Binding Instrument under the UN Convention on the Law of the Sea on the Conservation and Sustainable Use of Marine Biodiversity of Areas Beyond National Jurisdiction: 4-17 September 2018' (2018) 25 Earth Negotiations Bulletin 1, 3 .

${ }^{12}$ See, e.g., EJ Molenaar and AG Oude Elferink, 'Marine Protected Areas in Areas beyond National Jurisdiction: The Pioneering Efforts under the OSPAR Convention' (2009) 5 Utrecht Law Review 5, 9-10.

${ }^{13}$ The CBD provides that its provisions apply to 'components of biological diversity, in areas within the limits of its national jurisdiction'; CBD (n 4) art 4. However, within ABNJ, the CBD's provisions only apply to 'processes and activities, regardless of where their effects occur, carried out under its jurisdiction or control'; ibid. This could be seen as limiting the scope of the CBD to deal with biodiversity in ABNJ; see, e.g., Wright et al (n 3) 23 , fn 55

${ }^{14} \mathrm{Admittedly}$, the obligations under international law in this respect have been developed to some extent after the adoption of the LOSC. See, e.g., G Sander, 'International Legal Obligations for Environmental Impact Assessment and Strategic Environmental Assessment in the Arctic Ocean' in Freestone (n 3) 211, 218-232. Sander also provides an overview of weaknesses in the current legal regime, which includes 'a weak coverage of ABNJ'; ibid 216-218.
} 
The above issues have been discussed in tandem during the BBNJ process and in 2011, the General Assembly, acting upon the recommendation of the Ad Hoc Open-ended Informal Working Group to study issues relating to the conservation and sustainable use of marine biological diversity beyond areas of national jurisdiction, decided that these four issues had to be considered 'together and as a whole.' ${ }^{15}$

This brief summary of the background to the negotiations of the ILBI aptly indicates the intricacies involved in designing its institutional framework. The following points may be noted in this connection. First, the ILBI is required to address four distinct issues, which may require different institutional responses. Second, the ILBI will become part of the existing global and regional frameworks dealing with biological diversity beyond national jurisdiction. The General Assembly in defining the mandate of the intergovernmental conference has provided that 'the process and its result should not undermine existing relevant legal instruments and frameworks and relevant global, regional and sectoral bodies. ${ }^{16}$ Moreover, the General Assembly resolution provides that the 'work and results of the conference should be fully consistent with the provisions' of the LOSC. ${ }^{17}$ Third, the matter is further complicated by the fact that there is a strong resistance against the conference touching upon the regime of international fisheries. ${ }^{18}$ However, fishing most likely is the activity that impacts most on biological diversity in ABNJ and not addressing that activity in the ILBI and its institutional framework, in that light, might seem to be a fatal weakness.

\section{3 | THE CURRENT STATUS OF THE NEGOTIATIONS}

The debate at the first substantive session of the intergovernmental conference, which was convened from 4 to 17 September 2018, confirmed that the different elements of the package under consideration will require their own institutional responses. ${ }^{19}$ In relation to marine genetic resources, the options that were tabled for regulating access ranged from setting up a licensing permit or notification scheme to not dealing with the regulation of access to these resources at all. ${ }^{20}$ In dealing with the sharing of monetary benefits from these resources various options were proposed, taking into account existing frameworks; while for intellectual property rights

\footnotetext{
${ }^{15}$ UNGA 'Letter Dated 30 June 2011 from the Co-Chairs of the Ad Hoc Open-ended Informal Working Group to the President of the General Assembly' UN Doc A/66/119 (30 June 2011) Annex, para 1(b); UNGA 'Oceans and Law of the Sea' UN Doc A/ RES/66/231 (5 April 2012) para 167. This decision to treat the package identified in 2011 together and as a whole was reconfirmed in UNGA Resolution 72/249 (n 6) para 2. This package was put together as a compromise deal between developed and developing countries.

${ }^{16}$ UNGA Resolution 72/249 (n 6) para 7

${ }^{17}$ ibid para 6.

${ }^{18}$ See, e.g., C Blanchard, 'Fragmentation in High Seas Fisheries: Preliminary Reflections on a Global Oceans Governance Approach' (2017) 84 Marine Policy 327.

${ }^{19}$ The following summary is based on the reporting on the first session contained in UNGA 'Statement by the President of the Conference at the Closing of the First Session' UN Doc A/CONF.232/2018/7 (20 September 2018) (Statement by the President - First Session); and Morgera et al (n 11).

${ }^{20}$ Morgera et al (n 11) 6; Statement by the President - First Session (n 19) 22.
}

both a tailor-made system under the ILBI and leaving the matter to existing institutions were suggested. ${ }^{21}$ Possible bodies under an ILBI for dealing with marine genetic resources that were mentioned included a decision-making body, a scientific and technical body with advisory competence, a secretariat, a clearing-house mechanism and an access and benefit-sharing mechanism. ${ }^{22}$

The summary of the discussions on area-based management tools "identified a "spectrum of options" across global, hybrid, and regional proposals. ${ }^{23}$ The following options were specifically mentioned:

- establishing a coherent process for the establishment, implementation and enforcement of area-based management tools applicable to all States to address fragmentation, envisaging participation by competent organizations;

- relying more extensively on existing processes and frameworks, with some global-level decision making aimed at cooperation and coordination;

- strengthening existing regional bodies for enhanced cooperation and coordination between these and other relevant bodies, on the basis of model cooperation agreements that could be annexed to the ILBI; and

- outlining general principles and approaches under the ILBI, without oversight from a global mechanism and with States considering establishing competent organizations where they do not exist. ${ }^{24}$

Options that were mentioned in connection with a global body (e.g. the power to make binding decisions, including on the establishment of multi-purpose MPAs, ${ }^{25}$ presumably implying that fishing activities would also be regulated), further illustrate the divide about the role for existing bodies and a possible future global body. Proponents of a global body with decision-making power argued that this would be the only way of making the ILBI an effective instrument for coherently managing BBNJ. Under this scenario, the mandate of existing sectoral and regional bodies would be limited to a consultative role. ${ }^{26}$ The so-called 'hybrid approach' would seek to share competences between existing bodies and a new global body to be set up under the ILBI. The former in that case presumably would be charged with actual implementation of obligations flowing from the ILBI, while the new global body's task would be mostly involved in assessing the overall performance of regional bodies. ${ }^{27}$ Proponents of a regional approach, that is, giving prominence to existing bodies, considered that the ILBI should be limited to standard setting and not create a global body to deal with the issues of area-based management tools. ${ }^{28}$ It was also suggested that the ILBI should

\footnotetext{
${ }^{21}$ Morgera et al (n 11) 6.

${ }^{22}$ Statement by the President - First Session (n 19) 22.

${ }^{23}$ Morgera et al (n 11) 9.

${ }^{24}$ ibid; see also ibid 16 .

${ }^{25}$ ibid 9.

${ }^{26}$ ibid 16.

${ }^{27}$ See also ibid.

${ }^{28}$ ibid.
} 
not create a hierarchical relationship between a body under its aegis and regional and sectoral bodies. ${ }^{29}$

The report of the facilitator on EIAs indicates the absence of convergence between delegations on institutional arrangements. ${ }^{30}$ Delegates in favour of a role for an international component to EIA, and not leaving the whole process of implementation at the national level, proposed 'a decision-making body, a scientific body and a secretariat. Proposals were also put forward for a fund for the instrument and a compliance body. ${ }^{31}$

For the issue of capacity building and the transfer of marine technology, there was a general recognition that there would be a need for a mechanism to manage the implementation of ILBI in this respect. In that connection, it was both suggested to set up such a mechanism under the ILBI or to use existing mechanisms. ${ }^{32}$

The reports of the facilitators on the four issue areas to the conference contain a reference to the 'not undermining' requirement contained in the General Assembly Resolution setting up the conference in relation to three of those issue areas (marine genetic resources, areabased management tools and EIAs). ${ }^{33}$ The reports suggest that in the case of area-based management tools the reference is actively used in support of the regional approach and using existing mechanisms and resisting the calls for a strong global body, while in the other two cases the focus rather seems to be on avoiding unnecessary duplications. This may in large part be explained by the fact that existing interests in $\mathrm{ABNJ}$ are much more entrenched in existing institutions in the case of area-based management tools. For the other two issue areas it would be much harder to credibly argue that existing bodies provide an adequate regulatory framework, which would be 'undermined' by a proposed institutional structure under the ILBI. That said, the role of the 'not undermining' requirement in the negotiations should not be overestimated. The specific language of the resolution was acceptable to the various interests involved and certainly is flexible enough to justify different approaches to the institutional framework of the ILBI. For instance, a strong institutional component to the ILBI could be justified because it would enhance the effectiveness and coherence of the regime applicable to biodiversity in ABNJ. Regional and sectoral bodies could also be said to benefit from being embedded in such a global regime. $^{34}$

\footnotetext{
${ }^{29}$ Statement by the President - First Session (n 19) 11.

${ }^{30}$ ibid 20.

${ }^{31}$ ibid; see also Morgera et al (n 11) 12.

${ }^{32}$ Statement by the President - First Session (n 19) 8.

${ }^{33}$ ibid $11,16-17$ and 24.

${ }^{34}$ For a further discussion of this issue, see, e.g., Z Scanlon, 'The Art of "Not Undermining": Possibilities within Existing Architecture to Improve Environmental Protections in Areas beyond National Jurisdiction' (2017) 75 ICES Journal of Marine Science 1; A Friedman, 'Beyond "Not Undermining": Possibilities for Global Cooperation to Improve Environmental Protection in Areas beyond National Jurisdiction' (2019) 76 ICES Journal of Marine Science 452. Scanlon among others concludes that 'rather than seeking simply to "not undermine" existing architecture in ABNJ, focussing on and facilitating their efforts and abilities to take action and to adapt to improve environmental protections would be highly beneficial' (Scanlon, ibid 415). Friedman submits that consultation between existing bodies and the ILBI's institutional framework 'would catalyze regional and global cooperation to improve conservation and management outcomes in ABNJ' (Friedman, ibid 455). For a further discussion of the implications of the requirement of not undermining for the BBNJ process, see the text at the end of the next paragraph.
}

In January 2019, the President's aid to negotiations for the second session of the conference, which was convened from 25 March to 5 April 2019, was made available. ${ }^{35}$ This document was prepared upon a request of the conference to the President 'to prepare a document with the aim of facilitating focused discussions and text-based negotiation'. ${ }^{36}$ The document provides an overview of the different options that have been tabled for dealing with the individual issue areas. ${ }^{37}$ The options for the institutional arrangements of the ILBI were set out in a separate Section IV, ${ }^{38}$ while the sections dealing with the substantive issue areas make cross-references to this separate section in addressing institutional arrangements. Section IV presents a broad range of options, including the option to have no text in relation to any of the options it contains, for instance the ILBI in that case would not have any institutional arrangements. Apart from that 'no institutional arrangements' option, Section IV presents options for a decision-making body/forum; a scientific/technical body; other subsidiary bodies; and a secretariat. ${ }^{39}$ In setting out the options of the various bodies that might be included in the institutional arrangements of the ILBI, reference is made both to bodies to be set up under the instrument and using existing bodies. The President's aid to negotiations contains three options for addressing the requirement formulated by the General Assembly that the ILBI should not undermine existing relevant legal instruments and frameworks and relevant global, regional and sectoral bodies. ${ }^{40}$ These options provide an indication of the different ways of providing the requirement with specific content. Option II only repeats the requirement, without providing additional text. Option I emphasizes the need to respect existing instruments, frameworks and bodies. On the other hand, Option III refers to mutual support between the ILBI and the existing instruments, frameworks and bodies, and only requires due regard to be given to the latter 'provided that they are supportive of and do not run counter to the objectives of the Convention and [the ILBI]'. ${ }^{41}$ The presence of these options suggests that the design of the institutional framework of the ILBI will not be based on a specific interpretation of the term 'not undermine'. Rather, both issues most likely will be settled in tandem, or the provision dealing with the relationship of the ILBI with existing

\footnotetext{
${ }^{35}$ UNGA 'President's Aid to Negotiations' UN Doc A/CONF.232/2019/1 (3 December 2018, reissued 29 January 2019) (President's Aid). Although the original document is dated 3 December 2018, it was not available through the UN website until the second half of January 2019

${ }^{36}$ ibid paras 4-5.

${ }^{37}$ As the introduction of the document indicates: 'The order in which options appear in the present document should be taken neither as indicating any suggested order of priority, nor as an indication of the level of support for any particular option'; ibid para 7.

${ }^{38}$ In addition, Section $\mathrm{V}$ sets out the options in relation to a clearing-house mechanism, which is mostly intended as a means of exchanging relevant information.

${ }^{39} \mathrm{~A}$ footnote to the header of Section IV indicates that '[s] uggestions were made to take into account the structure, lessons learned and best practices of [existing] bodies and frameworks in developing provisions on institutional arrangements' and 'to utilize existing bodies'; ibid 57 , fn 13 .

${ }^{40}$ ibid 7 , Section II.4(2).

${ }^{41}$ ibid.
} 
instruments, frameworks and bodies will be settled after agreement on institutional design has been reached. ${ }^{42}$

The President's aid to negotiations for the second session of the conference met the wish of the conference to have a document that will assist 'facilitating focused discussions and text-based negotiation.. ${ }^{43}$ At the same time, the document indicated that all options are still on the table. The President's aid was at the centre of discussions during the second session of the conference, and the outcomes of the second session suggest that the President's aid helped narrowing down the options. ${ }^{44}$ The President's statement at the end of the second session indicates that there seemed to be convergence on endowing the ILBI with a conference of the parties, a scientific and/or technical body and a secretariat. ${ }^{45}$ At the same time, different views were expressed concerning the functions of these bodies and the need for further consideration of the matter. ${ }^{46}$ In advance of the third session of the conference, the President intends to make available a text that 'would likely be structured in a form more akin to a treaty, and containing treaty language'. ${ }^{47}$

\section{4 | SORTING OUT AND APPRAISING THE OPTIONS FOR INSTITUTIONAL ARRANGEMENTS}

In view of the widely diverging views on both the substantive issues and institutional arrangements to be included in the ILBI, the current section aims to tease out some of the advantages and drawbacks of the options that have been proposed and to envisage what the institutional arrangements of the ILBI, or the absence thereof, would imply for the (effectiveness of the) existing regime of the oceans beyond national jurisdiction. ${ }^{48}$

\footnotetext{
${ }^{42}$ The President's statement on the outcomes of the second session of the conference suggests that the discussion concerning 'not undermining' focused on the role the institutional framework of the ILBI could play in 'promoting coherence, complementarity and synergies' (UNGA 'Statement by the President of the Conference at the Closing of the Second Session' UN Doc A/CONF.232/2019/5 (18 April 2019) (Statement by the President - Second Session) 11; cf E Morgera et al, 'Summary of the Second Session of the Intergovernmental Conference on an International Legally Binding Instrument under the UN Convention on the Law of the Sea on the Conservation and Sustainable Use of Marine Biodiversity of Areas Beyond National Jurisdiction: 25 March-5 April 2018' (2019) 25 Earth Negotiations Bulletin 1, 18). The President's Statement does not refer explicitly to the concept of 'not undermining' in connection with the summary of the discussions concerning the institutional arrangements of the ILBI, but does mention that it would be useful to look at the relationship of the ILBI's main body 'to relevant global, regional and sectoral bodies' (Statement by the President - Second Session, ibid 21-22).

${ }^{43}$ President's Aid (n 35) 2

${ }^{44}$ See also Statement by the President - Second Session (n 42) 3-4.

${ }^{45}$ ibid 21-22. For information of the specific support for these different options, see Morgera et al (n 42) 13-14. States differed over whether the ILBI should establish other subsidiary bodies apart from the scientific and/or technical body. An alternative would be to assign a conference of the parties with the competence to establish subsidiary bodies (Statement by the President - Second Session (n 42) 22).

${ }^{46}$ Statement by the President - Second Session (n 42) 21-22.

47 ibid 2.

${ }^{48}$ The current analysis does not focus on the differences in institutional arrangements that may be required to deal with the four issue areas under consideration at the conference. It is acknowledged that these four issue areas may result in different institutional approaches in the ILBI.
}

To provide structure to the present discussion, it will start from the broad threefold distinction that has also been made at the conference: $^{49}$

(i) the global approach, with strong global institutional arrangements as part of the ILBI with decision-making power in relation to the substantive issue areas of the ILBI;

(ii) the hybrid approach, which would entail a focus on coordination and collaboration between the ILBI's institutions and existing regional and sectoral instruments without any hierarchy; and

(iii) the regional approach, implying the (near) absence of institutional arrangement of the ILBI, which for its implementation would depend on existing regional and sectoral frameworks. ${ }^{50}$

The appeal of the regional approach at face value is easily justified. It could be said to be cost-effective, as it does not require setting up new institutions that will for instance require funding, could lead to further fragmentation of the institutional landscape for oceans' governance, require the need to coordinate with existing bodies, lead to additional reporting obligations and take up additional meeting time of often already overburdened national government bodies. ${ }^{51}$ Moreover, the absence of new institutional arrangements under the ILBI, circumvents the difficult question of how to give specific expression to the relationship of the ILBI to existing institutional frameworks. ${ }^{52}$

However, as has been argued in the discussions on area-based management tools, not creating an institutional framework under the ILBI for this issue would imply that the ILBI would be limited to expressing global principles and would likely fail to accomplish the goal of a representative global network of MPAs. ${ }^{53}$ In that connection, reference was made to the experience of the Fish Stocks Agreement, which takes a similar approach. The Agreement provides general principles for the management of straddling fish stocks and highly migratory fish stocks, and assigns a central role in their implementation to regional bodies. The review mechanism of the Agreement lacks decision-making power in relation to these regional bodies. $^{54}$

\footnotetext{
${ }^{49} \mathrm{~A}$ similar threefold comparison has for instance been made in the Pew Charitable Trusts, 'Towards a Global Solution for High Seas Conservation: Protecting Marine Biodiversity beyond National Jurisdiction' (March 2017).

${ }^{50}$ It may be noted that there is general agreement that the ILBI will have to account for the fact that there are existing regional and sectoral arrangements (see Morgera et al (n 11) 16). At the same time, that recognition obviously does little to inform the options that are available to set up institutional arrangements under the ILBI. Proponents of a strong global body as part of the ILBI have also emphasized the significance of regional institutions for translating global commitment to the regional level. See, e.g., K Gjerde et al, 'Conservation and Sustainable Use of Marine Biodiversity in Areas Beyond National Jurisdiction: Options for Underpinning a Strong Global BBNJ Agreement through Regional and Sectoral Governance' (STRONG High Seas 2018) 11 and 14; see also C Durussel, E Soto Oyarzún and O Urrutia, 'Strengthening the Legal and Institutional Framework of the Southeast Pacific: Focus on the BBNJ Package Elements' (2017) 32 International Journal for Marine and Coastal Law 635, 637.

${ }^{51}$ For a further discussion of this point, see also Scanlon (n 34) 409-414

${ }^{52}$ For a discussion of this point in relation to the other two options, see below.

${ }^{53}$ Morgera et al (n 11) 16.

${ }^{54}$ See Fish Stocks Agreement ( $\mathrm{n} 2$ ) art 36 . For a further discussion of this point, see also below $\mathrm{n} 62$.
} 
The argument that an ILBI that would only contain substantive provisions, but would fail to include effective machinery for their implementation, would be ineffective, seemingly is convincing. As a matter of fact, most of the principles that have been suggested for inclusion in the ILBI are already part and parcel of different widely ratified conventions, such as the LOSC and the CBD, as well as customary international law. ${ }^{55}$ In other words, many of these principles have been around for decades, while the current negotiations are a clear indication that there is a broadly shared understanding that they have not been able to achieve that biodiversity in ABNJ is effectively managed and conserved.

An ILBI lacking strong institutional arrangements still might be able to achieve a more detailed elaboration and operationalization of existing principles. ${ }^{56}$ The Fish Stocks Agreement could again be taken as a case in point. Even before its entry into force on 11 December 2001, the principles included in the Agreement had been taken into account by States in reformulating the mandate of existing regional fisheries management organizations and in agreements setting up such organizations or arrangements in new regions. However, including these principles in the constitutive instruments of organizations or arrangements does not necessarily guarantee their effective implementation.

Apart from detailing existing principles, the ILBI could also be used to, for example, create reporting obligations for its State parties on their implementation of the ILBI individually and in regional and sectoral bodies. An existing global body could be charged with receiving and processing these reports. That obviously could include the possibility of an obligation for State parties to the ILBI to address issues that the global body would consider to be required to ensure implementation of obligations existing under the ILBI. Whether there actually is an existing global body that is adequately equipped to deal effectively with such a task may be doubted. Moreover, it may be doubted whether the proponents of a regional approach, who would seem to be satisfied with maintaining the current status quo, actually would be willing to provide it with mechanisms that would make it more akin to the hybrid approach.

The other two approaches to the institutional arrangements of the ILBI do raise the question how those arrangements would be related to existing institutional frameworks. The proponents of the hybrid approach have presented it as a possible compromise solution between the global and regional approaches, under which the existing mandates of regional bodies could be largely unaffected. ${ }^{57}$ One critique in this respect has been that 'those proposing a hybrid approach have not yet spelled out what this may mean'. ${ }^{58}$ Although that criticism probably could be applied equally to proponents of the other two approaches, 'spelling out' what the hybrid approach

\footnotetext{
${ }^{55}$ See, e.g., AG Oude Elferink, 'Governance Principles for Areas beyond National Jurisdiction' (2012) 27 International Journal of Marine and Coastal Law 205. As is observed by Young and Friedman, '[i]ndeed, there is already a robust set of environmental obligations in areas beyond national jurisdiction. What is lacking is implementation and compliance by states, and effective institutional support and oversight.' MA Young and A Friedman, 'Biodiversity beyond National Jurisdiction: Regimes and their Interaction' (2018) 112 American Journal of International Law 123, 126.

${ }^{56}$ See also Scanlon (n 34) 412-413.

${ }^{57}$ See, e.g., Morgera et al (n 11) 15.

${ }^{58}$ ibid
}

means does indicate that it raises similar questions in defining the relationship between the ILBI's institutional arrangements as the global approach does. For instance, how should these relationships be defined in legal terms, where the membership of the existing frameworks may be very different from that of the ILBI?

The hybrid approach has the obvious advantage that it may garner widespread support and be part of a widely supported compromise text. At the same time, the hybrid approach carries the risk of the ILBI ending up with institutional arrangements that lack the power to have any real impact on the implementation, or lack thereof, at the regional level. On the other hand, a hybrid approach that does provide the ILBI's institutional arrangements with teeth should perhaps rather be characterized as a variation of the global approach, instead of being in the separate category of the hybrid approach.

The inclusion of a conference of the parties or meeting of State parties or another decision-making body/forum in the institutional arrangements of the $\mathrm{ILBI}^{59}$ also raises the question how that body would relate to the meeting of State parties to the LOSC (SPLOS) and the UN General Assembly. ${ }^{60}$ If included in the ILBI, such a decision-making body likely would have an important role in relation to the (supervision of the) implementation of the instrument's substantive provisions. In that connection, the body might be confronted with issues concerning the interpretation or application of specific provisions of the ILBI that may also be relevant to interpretation and application of the LOSC or the body could be confronted with policy choices in relation to the development of the regime for $A B N J$. The latter is a task that currently is also carried out by the General Assembly, while the interpretation of the Convention is a task that primarily is a prerogative of its State parties. This issue might in particular become topical if the ILBI would not attract broad participation and the interests of the parties to the ILBI would differ significantly from the broader range of interests represented in the LOSC. Different interests could lead to diverging views on the development of the law. ${ }^{61}$

\footnotetext{
${ }^{59}$ These options are included in the President's Aid (n 35) 57, Section IV.1.

${ }^{60}$ The issue of the relationship of the institutional arrangements of the ILBI with the meeting of State parties to the LOSC and the UN General Assembly was brought to my attention by Liesbeth Lijnzaad. The current elaboration of this point is my sole responsibility.

${ }^{61}$ For a discussion of this point, see also DR Rothwell et al, 'Charting the Future for the Law of the Sea' in DR Rothwell et al (eds), The Oxford Handbook of the Law of the Sea (Oxford University Press 2015) 888, 909-910. It could be argued that the problem that is signalled here probably would not arise. First, the General Assembly has instructed the intergovernmental conference that its outcome should be fully consistent with the LOSC (UNGA Resolution 72/249 (n 6) para 6). This likely is to result in a provision in the ILBI addressing its relationship to the Convention. The President's aid to the negotiations contains the following option on this point: 'Nothing in this instrument shall prejudice the rights, jurisdiction and duties of States under the Convention. This instrument shall be interpreted and applied in the context of and in a manner consistent with the Convention' (President's Aid ( $n$ 35) 7). This is one of the few provisions in the President's aid to negotiations that does not contain different options. However, it is unlikely that the inclusion of such a provision completely excludes the possibility of diverging practice and interpretations. At the same time, having such a provision provides States with a strong argumentative tool to reject specific approaches under the ILBI. Moreover, it could be argued that the experience with the Fish Stocks Agreement indicates that the relationship between a body under the ILBI and other law of the sea frameworks should not be problematic. However, the parties under the Fish Stocks Agreement reflect a broad range of interests that would not seem to be dissimilar to the range of interests represented in the LOSC.
} 
As the preceding discussion indicates, a major concern in negotiating the ILBI is the avoidance of the potential for fragmentation of the law and decision-making procedures for implementing the law. The options for the institutional design that have been advanced during the BBNJ process, including at the intergovernmental conference, have different implications in that respect, and at the same time also may indicate that the States concerned assess the risk of fragmentation or the need of avoiding it differently. A regional focus, with the absence of a body with coordinating task at the global level, obviously carries the risk of regional differentiation. Moreover, such an approach may lead to a lack of coordination between the relevant regional bodies and between those bodies and sectoral bodies operating at the global level. Viewed from the perspective of States with strong regional interests, this has the obvious advantage that they can set the agenda at the regional level without involvement of or accountability to a global body.

If the ILBI will be equipped with a body with decision-making powers, the nature of those powers may vary significantly. For instance, global bodies that only review the performance of regional and sectoral bodies do not seem to be able to have much impact. The current regime for $A B N J$ already contains various reporting and review mechanisms, such as the Review conference of the Fish Stocks Agreement discussed above. ${ }^{62}$ And as has been observed by Freestone in an analysis that focuses on the issue of MPAs:

it is clear that the existing system does not provide an adequate framework for protecting high seas areas. There is little evidence that basic environmental precepts, including the ecosystem and precautionary ap proaches (contained in the key international legal and policy instruments), are being effectively applied by most international sectoral bodies. ${ }^{63}$

Freestone concludes his review concerning the options for a global body by observing that:

\begin{abstract}
The idea of a new permanent institution - such a[s] an Ocean Governance Authority - seems unlikely to be acceptable to the majority of states. However, a centralized system with a 'lighter touch' for establishing MPAs in the high seas ... seems to offer the greatest chance for success in achieving the conservation and sustainable use of high seas biodiversity. ${ }^{64}$
\end{abstract}

Freestone's analysis indicates that this centralized system would imply decision-making powers of a global body as regards the designation of MPAs, but otherwise would not affect the role of

\footnotetext{
${ }^{62} \mathrm{As}$ has also been observed by Young and Friedman ( $\mathrm{n}$ 55) 128: 'For example, the United Nations Fish Stocks Agreement encourages states to apply guiding principles and approaches within existing bodies without engaging in systematic or binding norm development. Attempts to develop a coherent set of practices through processes such as the joint meetings of the five tuna RFMOs initiated in Kobe, Japan, in 2007, have not progressed.'

${ }^{63}$ D Freestone, 'The Limits of Sectoral and Regional Efforts to Designate High Seas Marine Protected Areas' (2018) 112 American Journal of International Law 129, 133. ${ }^{64}$ ibid.
}

regional and sectoral bodies. ${ }^{65}$ Whether that approach would be sufficient to create an effective regime is open to discussion. Much would depend on how an area's status of MPA would impact on the management of existing and future activities, who would be responsible for reviewing that management and who would be able to implement changes in the management system if it were to fail to accomplish the principles set out in the ILBI. These are all questions that are directly related to the institutional arrangements to be contained in the ILBI. In that light, Mahon and others have argued that for the ILBI to be successful in enabling a coherent framework it should include: (i) a clearly identifiable overarching mechanism for integrated policy development and coordination; and (ii) effective science-policy advisory mechanisms to ensure that critical scientific knowledge is communicated effectively. ${ }^{66}$

The current negotiations on the ILBI illustrate the linkages between substantive issues and the accompanying institutional arrangements. The principles and rules that will be included in the ILBI will provide the substantive parameters within which institutions dealing with ABNJ will have to operate. On the other hand, the nature of the institutional arrangements will determine to what extent they can effectively engage with these principles and rules. It is submitted that the institutional framework of the ILBI constitutes the more critical issue in designing a regime that will accomplish the sustainability of ocean space beyond national jurisdiction. As the current analysis also indicates, there is no lack of substantive principles and rules. What is missing are effective mechanisms to ensure their successful implementation in practice. ${ }^{67}$

Moreover, it should be realized that the evolution of substantive principles and rules is easier to achieve than the redefinition of the institutional framework of a convention. This may be illustrated by developments in relation to the LOSC itself. Notwithstanding attempts by certain State parties to the Convention to broaden the mandate of the SPLOS, that mandate remains narrowly defined. That is most likely in line with the compromise when the Convention was negotiated, which is reflected in the language of the relevant provisions of the Convention. ${ }^{68}$ A significant redefinition of the mandate of the SPLOS would require having recourse to the cumbersome amendment procedures of the Convention. ${ }^{69}$ There can be little doubt that this is an option that is not going to be tested in the foreseeable future. On the other hand, the Convention's substantive

\footnotetext{
$65_{\text {ibid }} 130$.

${ }^{66} \mathrm{R}$ Mahon et al, 'Transboundary Waters Assessment Programme (TWAP) Assessment of Governance Arrangements for the Ocean. Volume 2: Areas Beyond National Jurisdiction' (UNESCO-IOC 2015) as quoted in Gjerde et al (n 50) 11

${ }^{67}$ It should however be acknowledged that this consideration does not apply evenly to al of the four issue areas under consideration at the conference. In particular the discussion on the issue of marine genetic resources could lead to different substantive outcomes, which would each imply the need for specific institutional responses. For a further discussion of this point, see G Voigt-Hanssen, 'Current "Light" and "Heavy" Options for Benefit-sharing in the Context of the United Nations Convention on the Law of the Sea' in Freestone (n 3) 243.

${ }^{68}$ This primarily concerns LOSC (n 1) art 319(2)(e). For a further discussion of the discussions about the mandate of the SPLOS, see AG Oude Elferink, 'Reviewing the Implementation of the LOS Convention: The Role of the United Nations General Assembly and the Meeting of States Parties' in AG Oude Elferink and DR Rothwell (eds), Oceans Management in the 21st Century: Institutional Frameworks and Responses (Martinus Nijhoff 2004) 295.

${ }^{69}$ See LOSC (n 1) arts 312-316.
} 
framework has been augmented significantly by developments in among others international environmental law after its adoption in 1982. An example is provided by the precautionary approach, which became widely accepted after that date and the relevance of which is among those recognized by the International Seabed Authority in fulfilling its mandate under the Convention. The precautionary approach is also included in the Fish Stocks Agreement. ${ }^{70}$ As its Article 2 indicates, the Fish Stocks Agreement is intended to effectively implement the Convention.

This adaptability in respect of substantive principles and rules is explained by the fact that they may also develop outside of the framework of the Convention and do not require to be incorporated into the Convention through its formal amendment procedures. The Convention itself provides for flexibility in this respect. ${ }^{71}$ For instance, its Article 87 provides that '[f]reedom of the high seas is exercised under the conditions laid down by this Convention and by other rules of international law'. ${ }^{72}$ The latter reference does not put any temporal limitation on the other rules of international law. In addition, the rules of international law formation imply that subsequent rules of customary law may also change or augment conventional obligations without the existence of such an explicit reference.

\section{5 | CONCLUSIONS}

The BBNJ process with the intergovernmental conference has entered a critical phase. At the preliminary stages of the conference, different options are still on the table. The outcome of the second session indicates that the ILBI will likely be endowed with a conference of the parties, a scientific/technical body and a secretariat, but the functions of these bodies remain to be decided. The reporting on the second session of the conference indicates that the latter point in the further negotiations will be the main contentious issue as regards the ILBI's institutional framework. ${ }^{73}$

To better understand the significance of the negotiations, it should be realized that they are taking place in the framework of a broader debate on the relationship between conservation and exploitation of the oceans. ${ }^{74}$ How to balance these interests is a question that the del-

\footnotetext{
${ }^{70}$ Fish Stocks Agreement (n 2) art 6 and Annex II.

${ }^{71} \mathrm{LOSC}$ (n 1) arts 237 and 311, which regulate the relation of the Convention with other agreements also envisage the further development of the law as contained in the Convention.

${ }^{72}$ ibid art 87

${ }^{73}$ See also Morgera et al ( $n$ 42) passim.

${ }^{74} \mathrm{~A}$ telling example in this respect is the debate on the establishment of MPAs in the Southern Ocean that has been taking place in the Commission on the Conservation of Antarctic Marine Living Resources, with certain States advocating the need for a comprehensive network of areas, while other States have frustrated such attempts because of the interest in fishing activities, arguing that a balance has to be struck between conservation and exploitation. See, e.g., S Earle, 'Will China Cast its Vote for Antarctica, and the Planet?' (Eco-Business, 26 October 2018). A more detailed review of the arguments of both sides is provided by the reports of the meetings of the Commission, which are available through the Commission's website: <https://www. ccamlr.org/en/meetings/>.
}

egates at the conference also will have to answer. Is the ILBI going to provide an effective framework for the sustainable governance of $A B N J$, which will allow the regulation of, and eventually limit or prohibit, specific activities that are at odds with that general objective?

The institutional arrangements of the ILBI are but one element of a highly complex negotiation. However, as this article submits, they are a critical element and perhaps even the central battle ground for determining whether the ILBI has the potential to live up to the expectation of providing an effective regime for the sustainability of the oceans beyond national jurisdiction. The absence of strong global institutional arrangements in the ILBI, will likely mean that the current uncoordinated approach to governing $A B N J$ will remain one of its central aspects.

\section{ORCID}

Alex G. Oude Elferink (iD https://orcid.org/0000-0002-3837-5217

Alex Oude Elferink is the Director of the Netherlands Institute for the Law of the Sea (NILOS) and an associate of the Utrecht Centre for Oceans, Water and Sustainability Law, School of Law, Utrecht University, the Netherlands. He also is an adjunct professor at the K.G. Jebsen Centre for the Law of the Sea, University of Tromsø, Norway. He is the author of The Delimitation of the Continental Shelf between Denmark, Germany and the Netherlands: Arguing Law, Practicing Politics? (Cambridge University Press 2013) and co-editor of The Oxford Handbook of the Law of the Sea (Oxford University Press 2015). Together with Petra Drankier, he was the guest editor of a special issue on Biological Diversity and Governance of Areas beyond National Jurisdiction (2012) 27(2) International Journal of Marine and Coastal Law. His current research is among others concerned with the legal regime of marine areas beyond jurisdiction and the future of the law of the sea. I want to thank the reviewer and the guest editors for their comments on a previous version of this article.

How to cite this article: Oude Elferink AG. Exploring the future of the institutional landscape of the oceans beyond national jurisdiction. RECIEL. 2019;28:236-243. https://doi. org/10.1111/reel.12301 